\title{
ASSESSMENT OF PERSONNEL STRENGTH AND QUALITY OF FOREST DEVELOPMENT FOR SUSTAINABLE DEVELOPMENT IN ABIA STATE, NIGERIA
}

\author{
Busuyi Olasina Agbeja ${ }^{1}$, Diana Chidi Olukwu-Kalu ${ }^{1}$ and Josiah Thomas B Riki ${ }^{2 *}$ \\ ${ }^{1}$ Department of Social and Environmental Forestry, Faculty of Renewable Natural Resources, \\ University of Ibadan, Ibadan, Nigeria \\ ${ }^{2}$ Department of Forestry and Wildlife Management, Faculty of Agriculture and Life Sciences, \\ Federal University Wukari, P.M.B 1020 Wukari, Taraba State, Nigeria
}

https://doi.org/10.35410/IJAEB.2020.5559

\begin{abstract}
The survival of the forest estate is largely dependent on the available workforce or manpower for maximum utilization and productivity of the forest estate. This study assessed personnel strength and quality of forest development for sustainable development in Abia State, Nigeria from 20082017. One hundred copies of questionnaires were administered to the randomly selected professionals, technicians and forest guards to assess the real workforce and adequacy of forest service's organogram. The variables obtained were subjected to both descriptive and inferential analyses. The results shows that there are nineteen (19) forest reserves in Abia State out of which 4 are natural forest while the remaining 15 are plantation forest reserves. The actual workforce in forest reserves were not adequate as only 2 professionals, 9 technicians and forest guards in the Natural forest while in the plantation forest there were 8 professionals, 20 technicians and forest guards. Results showed that $65 \%$ of the respondents said the forest service's organogram is adequate for delegation if properly followed. The empirical norm developed showed that there is shortage of staff as the ratio of professionals, technical staff on ground does not agree with the norm of 1 professional to 4 technical staff. Massive recruitment of staff is neededto improve personnel strength and quality of forest development for sustainable development in Abia State.
\end{abstract}

Keywords: Personnel strength, professional, technical, forest guards, forest reserves.

\section{INTRODUCTION}

It's hardly possible for any sustainable development to be achieved by any nation with unemployment and inadequate staffing which have become a major problem in managing the various sectors of theNigeria economy.The forestry sub-sector is not left out in this regard. Despite its overwhelming contributions, the sub-sector has manpower challenges in addressing the various problems of forest management in forest estates. At the passage of the forest laws in Nigeria in 1908 and the subsequent passage of other regional forest laws, certain forest areas were designated as forest reserves spanning through the mangrove, high rainforest to savannah. These areas (forest) remain the economic treasure house of the people who depend on these resources for their basic needs, commercial values and associated security (Bada and Popoola, 2005; Edetet al., 2017). 
Vol. 5, No. $05 ; 2020$

ISSN: $2456-8643$

This prevalent situation in many sub-Sahara African (SSA) countries thus, gives credence to the assertion that neither lack nor availability of renewable natural resources RNR determines the poverty status of any country but lack of appropriate and adequate human resources to develop and make use of science and technology in adding value to these RNR and also to attract investments. This scenario thus, constitutes part of the imperatives for sustained research and education in agriculture, forestry, other RNR management and related discipline in Africa if the objectives of Sustainable Millennium Development Goals (SDGs), especially tackling poverty and hunger, are to be achieved in this part of the world (Erakhrumen, 2007).

Forestry personnel are mandated to formulate and implementforest policies, enforce forest laws and develop forest resources. Other basic responsibilities of forestry personnel are to ensure efficient utilization of forest produce and services through guaranteeing economic viability and long term social and environmental benefit, protection of forest biodiversity and associated values in forest management, ensure legal and customary rights of rural communities undertake forest assessment and monitoring as well as recognize timber certification requirement. Basically, the personnel of any given forestry establishment comprises professional, technical, uniform/vocational and support staff. The professional personnel are often the unit heads that carry out administrative duties. The technical personnel carry out specialized duties like surveys,demarcations, and inventories. The responsibilities of the uniform/vocational personnel include patrols, detection of offenses and prosecution of forest offenses in courts of laws. The support personnel perform unspecialized duties. Typical examples of support staff are clerical assistants, messengers, cleaners, labourers, drivers, among others (Edetet al., 2017).

The forestry sector is one of the main pivots onwhich Nigeria's welfare was built, thereby making it a very important part of the country's economy. It ranks among one of the highest revenue and employment generating sectors and serves as a resource base for many forest industries. However, the unsustainable exploitation of the different types of forests, either natural orplanted, particularly the woody speciescomponent and their indiscriminate removal for other non-forest purposes coupled with the lack of current forest management plan(s), led to significant loss of these renewable natural resources where they can grow throughout the country. Therefore, series of sustainable forest management (SFM) intervention efforts have been suggested, adopted, and/or adapted in different instances for managing the remaining and proposed forests (Adeniyi, 2016).

Several studies (Akande et al., 2009; FAO, 2010) affirm that most state forestry services charged with the responsibility of managing the forest estate are underemployed or understaffed. Productivity is therefore generally low. Popoola (2014) noted that in the last 20 years, forest and park rangers, guards and other technical staff who were adequately equipped and lived within and around such forests, have all vanished due to inept governance, thus exposing the forest estates in many parts of Nigeria to encroachment and other vices. He also observed that where forest guards and rangers exist sparsely, they are poorly kitted, inadequately armed and poorly remunerated, hence they easily compromise. Akindele(2001), stated that many forest services are handicapped by shortage of trained personnel both in quantity and quality. If forestry administration is business-oriented, their primary functions should be the conservation, 
management, competent personnel based on the overall size of the forest estate. It is obvious that present administration of forest estate is not economically and environmentally satisfactory.

To achieve organizational goals and objectives, individual work needs to be coordinated and managed. Structure is a valuable tool in achieving coordination, as it specifies reporting relationships (who reports to whom), delineates formal communication channels, and describes how separate actions of individuals are linked together. However, in Abia State forest services, the problem of underemployed or understaffed and inadequacy of organogram is one of the major problem affecting the organization. The objectives of this study is to carry out assessment of personnel strength and quality as well as the adequacy of forest service's organogram for sustainable development in Abia State, Nigeriafor the past ten (10) years (2008 - 2017) with a view toimproving its administration.

\section{MATERIALS AND METHODS Study Area}

Abia is an acronym formed from the initial letters of four groups of people, namely: Aba, Bende, Isuikwuato and Afikpo. These constituted the major groups in the state at its creation. At the country's independence in 1960, Abia was part of the then Eastern Region. From 27th May, 1967, it became a part of the East Central State, created by the then Head of the Federal Military Government, General Yakubu Gowon. On 3rd February, 1976, East Central State was split into two states (Anambra and Imo) by the Federal Military Government headed by General Murtala Mohammed. On 27th August, 1991, the Federal Military Government under General Ibrahim Babangida carved out Abia State from Imo State, bringing to thirty the number of states in Nigeria.

Abia State lies within approximately latitudes $4^{\circ} 40^{\prime}$ and $6^{\circ} 14^{\prime}$ North, and longitudes $7^{\circ} 10^{\prime}$ and $8^{\circ}$ East (Figure 1). The state shares common boundaries to the north with Ebonyi State; to the south and southwest with Rivers State; and to the east and southeast with Cross River and Akwalbom States respectively.To the west is Imo State, and to the northwest is Anambra State. The state covers an area of about $5,243.7 \mathrm{sq}$. $\mathrm{km}$ which is approximately 5.8 per cent of the total land area of Nigeria. With its capital at Umuahia, it has seventeen Local Government Areas (Nigeriagalleria, 2018). 


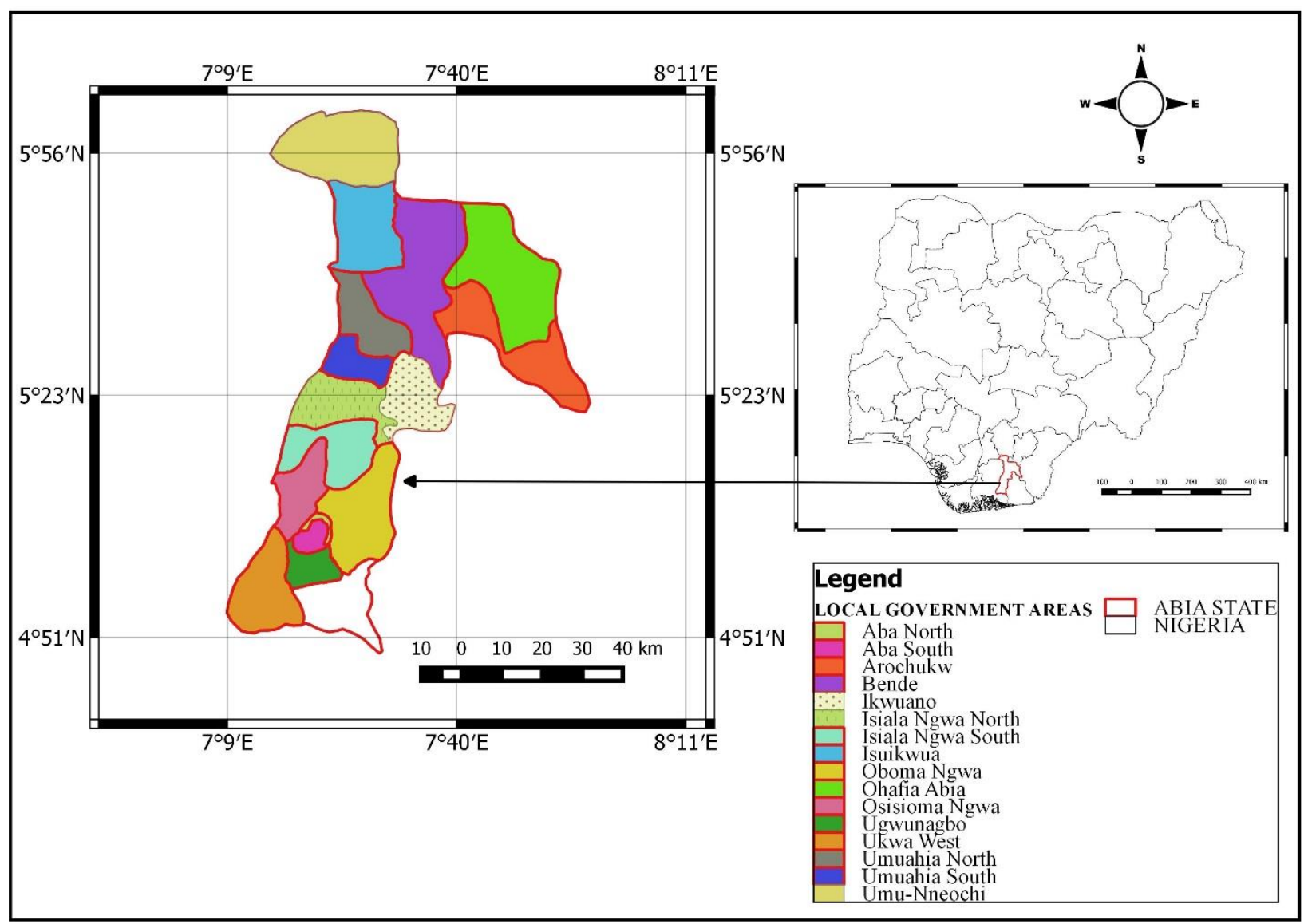

Figure 1. Map of the study area(Nigeriagalleria, 2018)

\section{Sampling Techniques}

A random sampling technique was used to collect data in the study locations using questionnaire and structured interviews with the senior forestry officials such as Abia State Deputy Director of forestry and some senior officers at the headquarters of the Forestry Department at the Ministry of Environment, Umuahia in Abia State. Correspondents were randomly selected in the Department of Forestry, Ministry of Environment and the total number of one hundred (100) questionnaires was used.

\section{Data Analysis}

The socio-economic survey data was subjected to both descriptive and inferential analyses. Simple percentage, Graph and Empirical norm model developed by FAO (1970) was used for the analysis.

\section{Empirical norms Model}

- Empirical norms of technical staff per management unit of forest reserve are a common practice used in the estimation of adequacy of forestry workers in forestry programme. 
- The development of empirical norms for technical demands considerable experience and detailed knowledge of operating conditions in a given forest (Enabor, 1981).

Estimates for the workload of professional and technical staff using the average area per staff was used to calculate it using the formula:

$$
\text { Indicative Workload }=\frac{\text { Area }}{\text { No.of staff }}
$$

\section{RESULTS AND DISCUSSIONS}

\section{Forest Reserves in Abia State}

There are nineteen (19) forest reserves located in various parts of the State. The status of these forest reserves are presented in Table 1.

Table 1: Forest Reserves in Abia State

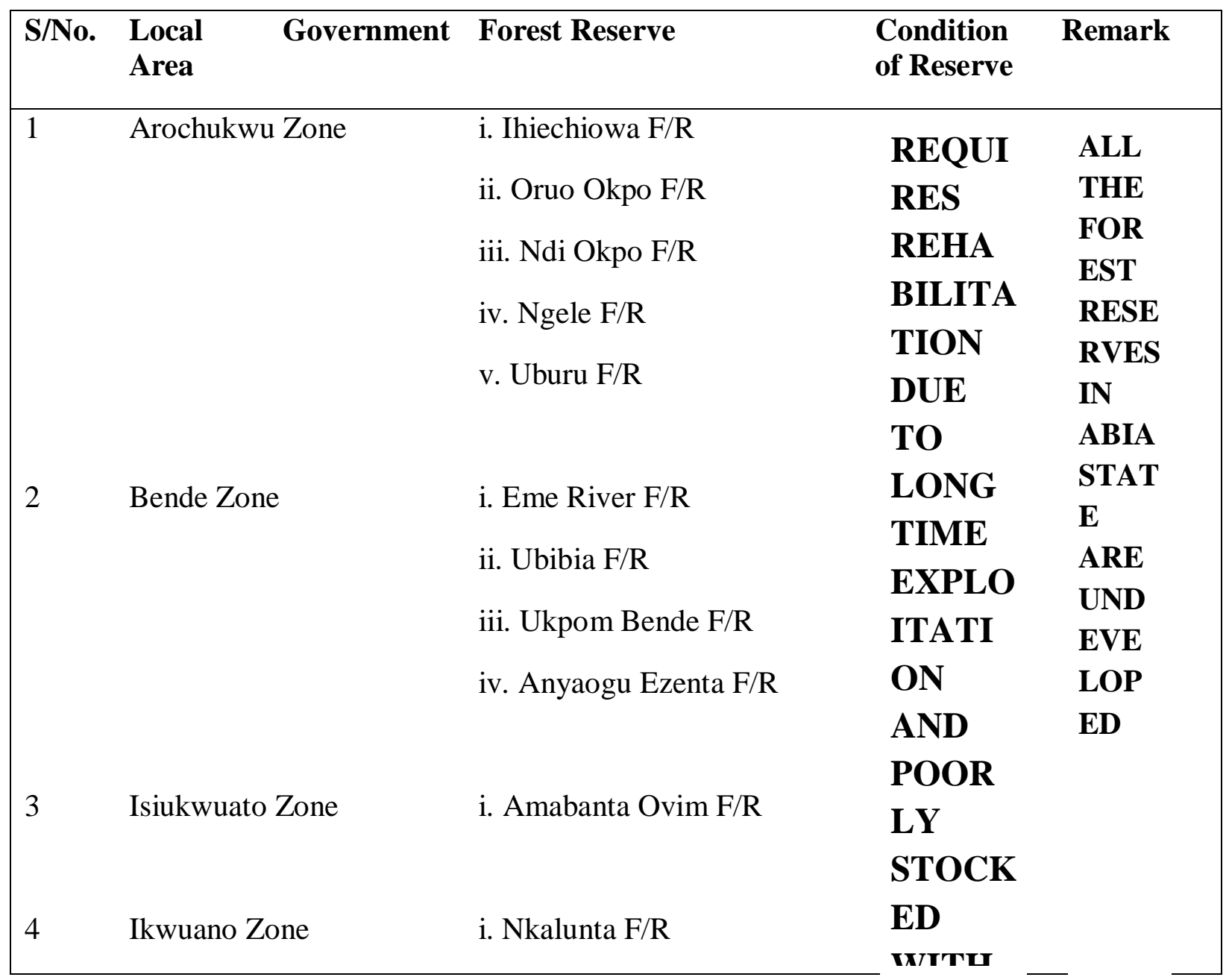




\begin{tabular}{|c|c|c|}
\hline 5 & Ohafia & i. Agukwu Amaekpu F/R \\
\hline 6 & Ukwa East Zone & $\begin{array}{l}\text { i. Obeaku F/R } \\
\text { ii. Ohambelem F/R }\end{array}$ \\
\hline 7 & Umunneochi & $\begin{array}{l}\text { i. Umuelem Isuochi F/R } \\
\text { ii. Umuelem extension I \& II } \\
\text { iii. Mgbeagu F/R }\end{array}$ \\
\hline 8 & Umuahia North F/R & i. Umuahia Ibeku \\
\hline
\end{tabular}

\section{Summary of Demographic Characteristics of the Respondents}

The staff strength of Abia State Forestry staff showed that there are more males than females (Table 2). Males accounted for $72.0 \%$ of the work force, while females accounted for $28.0 \%$.

This gives a male / female ratio of approximately 3:1, which was slightly below a ratio of 2:1 recorded byFAO (2003). This confirms Faleyimu (2010) findings that forestry activities and staff are men dominated.

The average age of personnel in any given organization is directly proportional to productivity of thatorganization. Also, the age factor in any given organization is significant because of the wisdom that comes with age. As indicated in Table 2, 41.70\% and 33.3\% of the personnel are within the productive age range (26- 36 and $36-45$ years).

The average age of personnel indicates that majority of the personnel of the Abia State Forestry staff are old andare not within the age bracket in which people are active at work, innovative and therefore cannot makemeaningful contribution to forest resources management even if adequately motivated. According to Asiabaka(1998), only young, energetic and innovative people can contribute meaningfully to agricultural enterprisesincluding forestry.

The educational qualification of majority $(44.0 \%)$ of the respondents were having secondary schoolcertificates, $24 \%$ with B.Sc./HND, followed by ND with $12.0 \%$ and. $20 \%$ of the respondents had M.Sc.The implication of the academic status from the result is that information dissemination by the administrative officers might make impact in carrying out various forest 
activities and programmes in the study areas since almost all respondents could read and write. This could also provide more knowledge that increased the staff's rationality in the use of innovations.

Table 2: Demographic Characteristics of Respondents

\begin{tabular}{|c|c|c|c|}
\hline Variables & Responds & Frequency & Percentage (\%) \\
\hline \multirow[t]{3}{*}{ Sex } & Male & 54 & 72.0 \\
\hline & Female & 21 & 28.0 \\
\hline & Total & 75 & 100.0 \\
\hline \multirow[t]{6}{*}{ Age } & $18-25$ & 3 & 4.2 \\
\hline & $26-35$ & 30 & 41.7 \\
\hline & $36-45$ & 24 & 33.3 \\
\hline & $46-55$ & 12 & 16.7 \\
\hline & $>55$ & 3 & 4.2 \\
\hline & Total & 72 & 100.0 \\
\hline \multirow[t]{5}{*}{ Academic Status } & $\begin{array}{l}\text { Masters } \\
\text { degree }\end{array}$ & 15 & 20.0 \\
\hline & $\begin{array}{l}\text { Bachelors } \\
\text { degree }\end{array}$ & 18 & 24.0 \\
\hline & Diploma/NCE & 9 & 12.0 \\
\hline & $\begin{array}{l}\text { Secondary } \\
\text { school }\end{array}$ & 33 & 44.0 \\
\hline & Total & 75 & 100.0 \\
\hline
\end{tabular}

Source: Field survey, 2018. 
Table 3, showed that people with $2-5$ years had the highest percentage of $28.0 \%$, followed by those with $6-10$ years with $24.0 \%, 20 \%$ with $<20$ years, $16 \%$ with $11-15$ years and the least was those with $>15$ years and above.

Category of staff that is been employed most in the Forestry Department of Abia State are the technician with $58.3 \%$ followed by the professionals with $29.2 \%$ and lastly the forest guards with $12.5 \%$. From my interviewed with the deputy director, it was revealed that the reason why there are low numbers of forest guards because most of them were employed as forest guards but later further for diploma and other higher programmes to improve their selves for better management.

Category of staff of staff result revealed that adequate participation in forest management has become an essential element in decision making that guidesthe survival of forest resources (Edet et al., 2017). Years of experience in Forestry profession result showed that most of the forestry staff in Abia State has no experience in the field but find their way into the Department through politicians.

Table 3: Demographic Characteristics of Respondents Cont'd

\begin{tabular}{|llcc|}
\hline Variables & Responds & Frequency & Percentage (\%) \\
\hline $\begin{array}{llc}\text { Years of experience in Forestry } \\
\text { profession }\end{array}$ & $<2$ years & 15 & 20.0 \\
& $2-5$ years & 21 & 28.0 \\
& 6-10years & 18 & 24.0 \\
& $11-15$ years & 12 & 16.0 \\
& $>15 y e a r s$ & 9 & 12.0 \\
& Total & $\mathbf{7 5}$ & $\mathbf{1 0 0 . 0}$ \\
& & & \\
Category of staff & Professional & 21 & 29.2 \\
& Technical & 42 & 58.3 \\
& Forest Guard & 9 & 12.5 \\
\hline & Total & $\mathbf{7 2}$ & $\mathbf{1 0 0 . 0}$ \\
\hline
\end{tabular}

Source: Field survey, 2018.

Results for Assessment of Actual Workforce in the Forest Reserves 
Table 4 showed that the size of the forest reserves and the number of staff i.e the professionals, technicians and the forest guards in all the 19 Forest reserves in Abia State.

The workload of technical staff depends on the size of forest estate, the intensity and techniques of management and nature of projects to be implemented. As well as the size and experience of the subordinate staff (Enabor, 1981).

The workload of technical staff depends greatly on the intensity of forest management. This implies that the larger the area of proposed plantation and the more intensive the degree of logging, the higher the number of technical staff required per unit area (Enabor, 1981).

Table 4: Indicative workload for professional staff in Natural forest in Abia State

\begin{tabular}{|lllll|}
\hline Abia State & L.G.A & Area (Ha) & $\begin{array}{l}\text { No. of } \\
\text { Professional } \\
\text { Staff }\end{array}$ & $\begin{array}{l}\text { Size per } \\
\text { Professional } \\
\text { staff }\end{array}$ \\
Natural Forest & & 186.14 & 1 & 186.14 \\
\hline Ngele F/R & Arochukwu & & & \\
Nkalunta F/R & Ikwuano & 364 & - & - \\
Ohambele F/R & Ukwa East & 600 & 1 & 600 \\
& & & - & - \\
Mgbeagu F/R & Umunneochi & 43 & & \\
& & & & \\
\hline
\end{tabular}

Source: Field Survey, 2018. $\quad$ Note: N/R=Forest Reserve

Table 5 shows the indicative workload for technician staff in natural forest in Abia State. The results shows that only 9 technical staff and Table 6 shows 9 guards are in the natural forests.

Table 5: Indicative workload for Technician staff in Natural forest in Abia State

\begin{tabular}{|c|c|c|c|c|}
\hline Abia State & L.G.A & Area (Ha) & $\begin{array}{l}\text { No. of } \\
\text { Technical } \\
\text { Staff }\end{array}$ & $\begin{array}{l}\text { Size per } \\
\text { Technical staff } \\
\text { (Ha) }\end{array}$ \\
\hline \multicolumn{5}{|c|}{ Natural Forest } \\
\hline
\end{tabular}




\begin{tabular}{|llccc|}
\hline Ngele F/R & Arochukwu & 186.14 & 2 & 93.07 \\
Nkalunta F/R & Ikwuano & 364 & 2 & 182.0 \\
Ohambele F/R & Ukwa East & 600 & 3 & 200 \\
Mgbeagu F/R & Umunneochi & 43 & 2 & 21.5 \\
& & & & \\
\hline
\end{tabular}

Source: Field Survey, 2018. Note: F/R=Forest Reserve

Table 6: Indicative workload for Forest Guards in Natural forest in Abia State

\begin{tabular}{|lllll|}
\hline Abia State & L.G.A & Area (Ha) & $\begin{array}{l}\text { No. of Forest } \\
\text { Guards }\end{array}$ & $\begin{array}{l}\text { Size per } \\
\text { Forest Guards } \\
\text { (Ha) }\end{array}$ \\
Natural Forest & & & & \\
\hline Ngele F/R & Arochukwu & 186.14 & 3 & 62.05 \\
Nkalunta F/R & Ikwuano & 364 & 2 & 182.0 \\
Ohambele F/R & Ukwa East & 600 & 2 & 300 \\
Mgbeagu F/R & Umunneochi & 43 & & 21.5 \\
& & & 2 & \\
\hline
\end{tabular}

Source: Field Survey, 2018. Note: F/R=Forest Reserve 
Table 7 reveals that there are 9 professional staff in plantation forest in the State.

Table 7: Indicative workload for Professional Staff in Plantation forest in Abia State

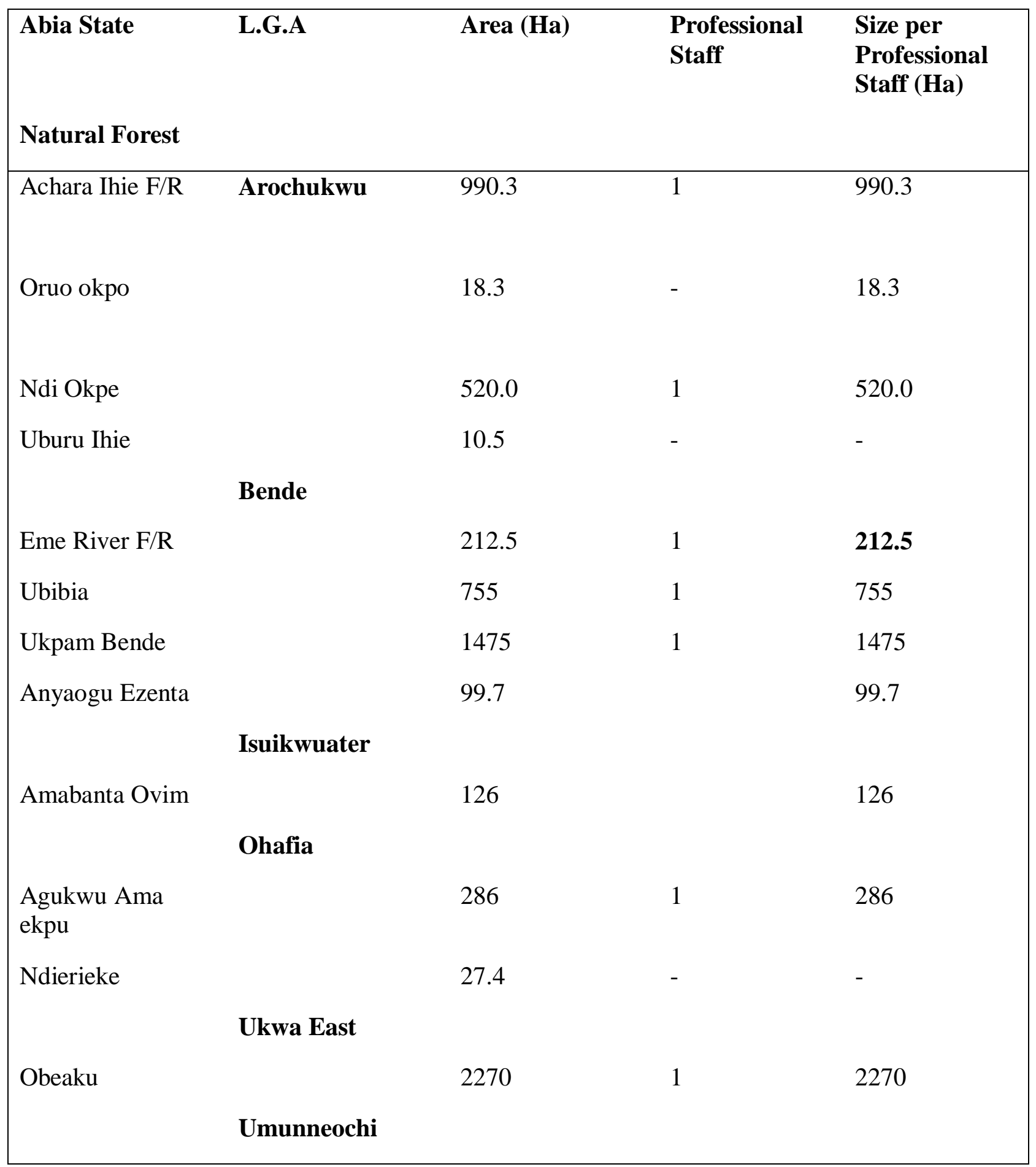


Vol. 5, No. 05; 2020

ISSN: $2456-8643$

Umuelem Isuochi

11.7

11.7

Umuelem

108.7

1

108.7

extention I and II

\section{Uuahia Ibeku}

Unuahia North

120

1

120

\section{Source: Field Survey, 2018. Note: F/R=Forest Reserve}

Results in Table 4,5,6 and 7 indicates that the workload for the professional staff, technical staff and Forest guards in each forest reserves in Abia State as the whole State based on the total area of natural forest and plantation forest and their available manpower.

It is difficult to say whether or not the workloads are heavy without developing a kind of norm or standard which might also be used to estimate requirement. This is done in the section below.

It has not been possible to obtain from the forestry officials in the three states useful guidelines on norms for technical staff. After a careful consideration of estimates provided in other sources (FAO 1970; Enabor, 1981) and of the forest conditions and management techniques the following empirical norms for technical staff are suggested and adopted for the study.

Table 8 reveals that there are 20 numbers of technical staff and forest guards in the plantation forest in Abia State.

Table 8: Indicative workload for Technical Staff in Plantation forest in Abia State

\begin{tabular}{|lllll|}
\hline Abia State & L.G.A & Area (Ha) & $\begin{array}{l}\text { No. of } \\
\text { Technical staff }\end{array}$ & $\begin{array}{l}\text { Size per } \\
\text { Technical staff } \\
\text { (Ha) }\end{array}$ \\
Natural Forest & & & & \\
\hline Achara Ihie F/R & Arochukwu & 990.3 & 2 & 495.15 \\
Oruo okpo F/R & & 18.3 & 1 & 18.3 \\
Ndi Okpe & & 520.0 & 2 & 260 \\
Uburu Ihie & & 10.5 & 1 & 10.5 \\
Eme River F/R & & & 2 & 106.25 \\
\hline
\end{tabular}




\begin{tabular}{|c|c|c|c|c|}
\hline Ubibia & & 755 & 1 & 755 \\
\hline Ukpam Bende & & 1475 & 2 & 737.5 \\
\hline \multirow[t]{2}{*}{ Anyaogu Ezenta } & & 99.7 & 1 & 99.7 \\
\hline & Isuikwuater & & & \\
\hline \multirow[t]{2}{*}{ Amabanta Ovim } & & 126 & 1 & 126 \\
\hline & Ohafia & & & \\
\hline AgukwuAma ekpu & & 286 & 1 & 286 \\
\hline \multirow[t]{2}{*}{ Ndierieke } & & 27.4 & 1 & 27.4 \\
\hline & Ukwa East & & & \\
\hline \multirow[t]{2}{*}{ Obeaku } & & 2270 & 2 & 1135 \\
\hline & Umunneochi & & & \\
\hline Umuelem Isuochi & & 11.7 & 1 & 11.7 \\
\hline \multirow{2}{*}{$\begin{array}{l}\text { Umuelem } \\
\text { extention I and II }\end{array}$} & & 108.7 & 1 & 108.7 \\
\hline & Uuahia Ibeku & & & \\
\hline Unuahia North & & 120 & 1 & 120 \\
\hline
\end{tabular}

Source: Field Survey, 2018. Note: F/R=Forest Reserve

Table 9: Indicative workload for Forest Guards in Plantation forest in Abia State

\begin{tabular}{|lllll|}
\hline Abia State & L.G.A & Area (Ha) & $\begin{array}{l}\text { No. of Forest } \\
\text { Guards }\end{array}$ & $\begin{array}{l}\text { Size per } \\
\text { Forest Guards } \\
\text { (Ha) }\end{array}$ \\
Natural Forest & & & & \\
\hline Achara Ihie F/R & Arochukwu & 990.3 & 2 & 495.15 \\
Oruo okpo F/R & & 18.3 & 1 & 18.3 \\
& & & & \\
\hline
\end{tabular}


Vol. 5, No. 05; 2020

ISSN: $2456-8643$

\begin{tabular}{|c|c|c|c|c|}
\hline Ndi Okpe & & 520.0 & 2 & 260 \\
\hline \multirow[t]{2}{*}{ Uburu Ihie } & & 10.5 & 1 & 10.5 \\
\hline & Bende & & & \\
\hline Eme River F/R & & 212.5 & 2 & 106.25 \\
\hline Ubibia & & 755 & 1 & 755 \\
\hline Ukpam Bende & & 1475 & 2 & 737.5 \\
\hline \multirow[t]{2}{*}{ Anyaogu Ezenta } & & 99.7 & 1 & 99.7 \\
\hline & Isuikwuater & & & \\
\hline \multirow[t]{2}{*}{ Amabanta Ovim } & & 126 & 1 & 126 \\
\hline & Ohafia & & & \\
\hline $\begin{array}{l}\text { Agukwu Ama } \\
\text { ekpu }\end{array}$ & & 286 & 1 & 286 \\
\hline \multirow[t]{2}{*}{ Ndierieke } & & 27.4 & 1 & 27.4 \\
\hline & Ukwa East & & & \\
\hline \multirow[t]{2}{*}{ Obeaku } & & 2270 & 2 & 1135 \\
\hline & Umunneochi & & & \\
\hline Umuelem Isuochi & & 11.7 & 1 & 11.7 \\
\hline \multirow[t]{2}{*}{$\begin{array}{l}\text { Umuelem } \\
\text { extention I and II }\end{array}$} & & 108.7 & 1 & 108.7 \\
\hline & Uuahia Ibeku & & & \\
\hline Unuahia North & & 120 & 1 & 120 \\
\hline
\end{tabular}

\section{Source: Field Survey, 2018. Note: F/R=Forest Reserve}

Generally, there are fifty-four (54) staff deployed at the various zonal forest offices and the headquarters at Umuahia. This number is grossly inadequate considering that the entire state has to be covered. From the above calculation, the available staff and the estimated requirement are not in agreement with the norm because the norm says one (1) professional to four (4) technicians. It is obvious that a massive recruitment is needed for effective management of the forest estates in each forest reserves. This study revealed a shortage of staff in Abia State forest service especially the technicians and this will affect their ability to effective forestry sector's 
goals and also hinder development of the forestry services. This is in consonance with the report of Bada (1994), who observed that there was acute shortage of manpower in Nigerian forestry sub-sector both in quantity and quality. In the same vein, Oguntala (1994) pointed out that in some countries where there are policies and plans for management, necessary quantity and quality of manpower is not available.

Furthermore, according to Famuyide and Adebayo (1993) forest management not only requires experienced and knowledgeable foresters but also depends on skilled and dedicated workers for effective management of the forest. The lack of professional foresters e.g the technicians therefore will not only cause a dislocation in forest services, it will also becloud the future developments and challenges which might present them. Alao (2005) further stated that generally, shortages of forestry personnel have been endemic, deep rooted and protracted for a long while as a result of subtle moratorium on employment by the government of the federation and that whenever this is lifted and employment conditions favorable, the gaps in the forestry manpower or shortages in the States forest services will be bridge.

Several studies (Alao, 2005; Akindele, 2008; Akande et al, 2009) affirm that most state forestry services charged with the responsibility of managing the forest estate are underemployed or understaffed. Productivity is therefore generally low. Faleyimu and Arowosoge (2011) observed that out of a total of two hundred and ninety three staff expected to handle the activities of the forestry project in Kaduna State; only one hundred and ninety-three staff $(65.87 \%)$ were available. In a similar vein, Popoola (2014) noted that in the last 20 years, forest and park rangers, guards, and other technical staff who were adequately equipped and lived within and around such forests, have all vanished due to inept governance, thus exposing the forest estates in many parts of Nigeria to encroachment and other vices. He also observed that where forest guards and rangers exist sparsely, they are poorly kitted, inadequately armed and poorly remunerated, hence they easily compromise. If forestry administration is business-oriented, their primary functions should be the conservation, management, and sale of forest products; hence, it is pertinent to have good organization, structure and management, competent personnel based on the overall size of the forest estate. It is obvious that present administration of forest estate is not economically and environmentally satisfactory.

\section{Adequacy of Forest Service's Organogram}

Table 10 shows that relationship between demographic information and adequacy of forest organogram depicting its probability level which shows that if the relationship is significant or not. All P-values higher than 10\%, 5\% and 1\% are not significant and values lower than them are significant.

Table 10 showed that the respondents view staff adequate to prosecute daily activities does not depend on their rank, but the implementation of the promotion of forest officials depend on their rank and educational status. Generally, there is a significant difference between the demographic information of the staff with respect to service's organogram of the Department of Forestry in Abia State. 
The result of Forest Service's Organogram corroborated with that of Adekunle et al., (2011) who also reported shortage number of forestry staff in Nigeria. There are nineteen (19) forest reserves in Abia State out of which four (4) are natural forests while the remaining nine (9) are plantation forest reserves. This result agrees with that of FAO (2010).

Apart from the director and deputy director, most of the staff have no forestry background and also the structure i. e organogram is viable for the management of forest reserves with as $60 \%$ of the respondent agreed to it while $40 \%$ disagreed that it is not viable but since the percentage of those who agreed is higher, majority carry the vote. The poor management could be attributed to government negligence to attain to forestry needs even though its is one of the department that do generate the highest revenue in the state.

Table 10: Interaction between Background Information and Adequacy of Forest Organogram

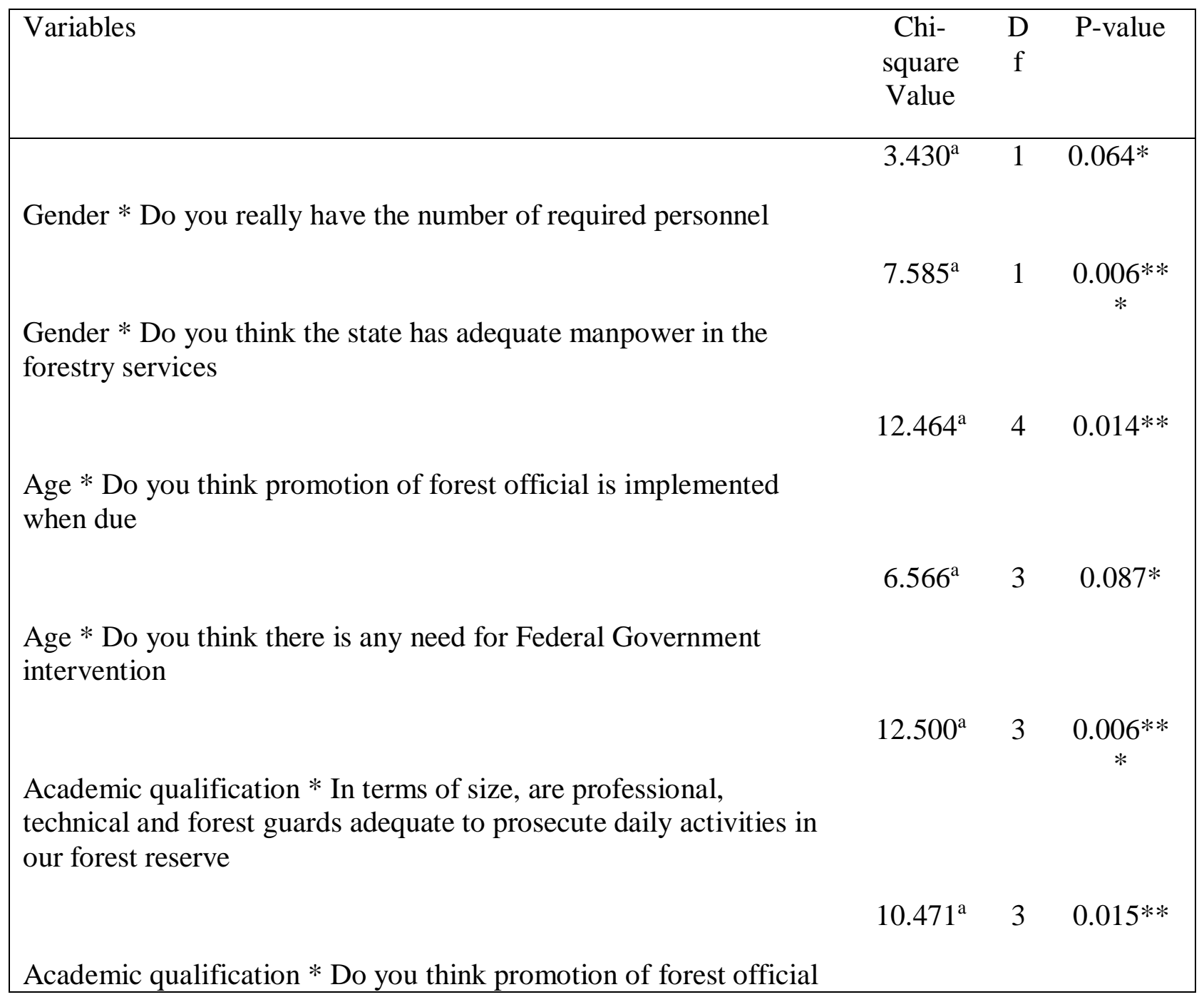


Vol. 5, No. 05; 2020

ISSN: 2456-8643

is implemented when due

$20.000^{\mathrm{a}} \quad 3 \quad 0.000 * *$
$*$

Academic qualification * Do you think there is any need for Federal Government intervention

\begin{tabular}{|c|c|}
\hline $16.327^{\mathrm{a}}$ & 4 \\
\hline
\end{tabular}

How long have you been in Forestry profession * Do you really have the number of required personnel

$8.036^{\mathrm{a}} \quad 4 \quad 0.090^{*}$

How long have you been in Forestry profession * In terms of size, are professional, technical and forest guards adequate to prosecute daily activities in oou forest reserve

How long have you been in Forestry profession * Do you think the state has adequate manpower in the forestry services

$17.235^{\mathrm{a}} \quad 4 \quad 0.002 * *$
$*$

How long have you been in Forestry profession * Do you think

$\begin{array}{ccc}26.667^{\mathrm{a}} & 4 & 0.000^{* *} \\ *\end{array}$
there is any need for Federal Government intervention

$4.735^{\mathrm{a}} \quad 2 \quad 0.094^{*}$

Category of staff $*$ Do you really have the number of required personnel

$7.602^{\mathrm{a}} \quad 2 \quad 0.022 * *$

Category of staff * In terms of size, are professional, technical and forest guards adequate to prosecute daily activities in oou forest reserve

$$
\begin{array}{cc}
17.143^{\mathrm{a}} & 2 \quad 0.000^{* *} \\
*
\end{array}
$$

Category of staff * Do you think promotion of forest official is implemented when due

$4.675^{\mathrm{a}} \quad 2 \quad 0.097 *$

Category of staff * Do you think the state has adequate manpower in the forestry services 
Vol. 5, No. 05; 2020

ISSN: 2456-8643

$\begin{array}{ccc}20.000^{\mathrm{a}} & 2 & \begin{array}{c}0.000^{* *} \\ *\end{array}\end{array}$

Category of staff * Do you think there is any need for Federal Government intervention

$*=$ significant at $10 \%, * *=$ significant at $5 \%, * * *=$ significant at $1 \%$

Table 11 showed that the forest service's organogram is adequate for delegation of duty/authority as $65.2 \%$ said yes while $34.8 \%$ said no. $96 \%$ of the respondents said there is no adequate manpower to prosecute daily activities in Abia forest reserves. Also, $75 \%$ of the respondents agreed that the Director and deputy director had forestry background. $60 \%$ of the respondents said they think the structure of the organogram is viable for the management of forest reserve while $40 \%$ said it is not. It is evident that our forest reserves need adequate officials for its management in Nigeria. This showed that the forest service in Abia State shows that there are no enough staff to manage the forest reserves.

Table 11: To Assess the Adequacy of the Forest Service's Organogram Cont'd

\begin{tabular}{|lccc|}
\hline Variables & Responds & Frequency & $\begin{array}{c}\text { Percentage } \\
(\mathbf{\%})\end{array}$ \\
\hline $\begin{array}{l}\text { Our constituted forest reserve needs } \\
\text { adequate number of forest official for the } \\
\text { management. Is forest services } \\
\text { organogram adequate for delegation of } \\
\text { duty/authority }\end{array}$ & Yes & 45 & 65.2 \\
& No & 24 & 34.8 \\
$\begin{array}{l}\text { In terms of size, are professional, technical } \\
\text { and forest guards adequate to prosecute } \\
\text { daily activities in Abia forest reserve }\end{array}$ & Yes & $\mathbf{6 9}$ & $\mathbf{1 0 0 . 0}$ \\
& No & 72 & 4.0 \\
& Total & $\mathbf{7 5}$ & $\mathbf{1 0 0 . 0}$ \\
\hline $\begin{array}{l}\text { Starting from the director, does he/she } \\
\text { have forestry background }\end{array}$ & Yes & 75 & 100.0 \\
\hline & Total & $\mathbf{7 5}$ & $\mathbf{1 0 0 . 0}$ \\
\hline
\end{tabular}




\begin{tabular}{|lccc|}
\hline $\begin{array}{l}\text { Looking at the organogram, do you think } \\
\text { the structure is viable for the management } \\
\text { of forest reserve }\end{array}$ & Yes & 45 & 60.0 \\
& No & 30 & 40.0 \\
& Total & $\mathbf{7 5}$ & $\mathbf{1 0 0 . 0}$ \\
\hline
\end{tabular}

Source: Field survey, 2018.

Results in Table 12 showed that $84.0 \%$ of the respondents said there is no required number of personnel in Forestry Department in Abia State, $72.0 \%$ agreed that the promotion of forest officials are not implemented as at when due while $28 \%$ disagreed, whenever there is retrenchment of any staff or dismissed, $64 \%$ of the respondents said the gap will not be filled and even when fill, it will be somebody with no forestry background.

Table 12: To Assess the Adequacy of the Forest Service's Organogram

\begin{tabular}{|lccc|}
\hline Variables & Responds & Frequency & Percentage (\%) \\
\hline $\begin{array}{l}\text { Do you really have the number of } \\
\text { required personnel }\end{array}$ & Yes & 12 & 16.0 \\
& No & 63 & 84.0 \\
$\begin{array}{l}\text { Do you think promotion of forest } \\
\text { official is implemented when due }\end{array}$ & Yes & 21 & $\mathbf{1 0 0 . 0}$ \\
& No & 54 & 72.0 \\
$\begin{array}{l}\text { when there is retrechment or } \\
\text { dismissal of a staff, do you fill the } \\
\text { vacancy immediately to fill the gap } \\
\text { in the organogram for continuity } \\
\text { of office bearer }\end{array}$ & Yes & $\mathbf{7 5}$ & $\mathbf{1 0 0 . 0}$ \\
\hline
\end{tabular}


International Journal of Agriculture, Environment and Bioresearch

Vol. 5, No. 05; 2020

ISSN: $2456-8643$

\begin{tabular}{|ccc|}
\hline No & 48 & 64.0 \\
Total & $\mathbf{7 5}$ & $\mathbf{1 0 0 . 0}$ \\
\hline
\end{tabular}

Source: Field survey, 2018.

\section{CONCLUSIONS AND RECOMMENDATIONS}

This study has been able to assess forestry administration in Abia State for the past ten (10) years i.e from 2008-2017. The nineteen (19) forest reserves in Abia State out of which four (4) are natural forest reserves and the remaining fifteen (15) are plantation forest reserves. These reserves are experiencing staff shortage and any planned intensification of plantation establishment or natural forest management will require additional hands or will fail.

The results showed a great discrepancy between the norm and the number of staff on ground, this means that the number of staff available is not enough to effectively manage the forest estate as a result of depletion, illegal encroachment and farming and also felling of logs especially from Okwoyi in Umuahia and Amamba community in Uzuakoli of Abia State. The effect of low personnel especially the technicians in Abia State in zones with hemp growers, illegal fellers and farmers with forestry staff stretched thin trying to curtail the problem and increase in number of staff and facilities such as standard vehicles and motorcycles are needed to facilitate in surveillance operations in order to curb or at least reduce this incidence to the barest minimum. Massive recruitment of staff at all levels and across each zones should be done, for sustainability of our forest estate to occur and the existing facilities are insufficient to meet the additional staff requirement, expansion and improvement of these facilities is therefore strongly recommended in order to meet the requirement of staff in the forestry services of Abia State.

\section{REFERENCES}

Adekunle, V. A. J., Okunola, J. O. and Oke, D. O. 2011. Management of Forest Ecosystem for Food Security and Rural Livelihood in South West Nigeria. 143 pp.

Adeniyi, P. A. 2016. Environmental Sustainability and Conservation of Nigeria Forest Reserves Journal of Geography, Environment andEarth Science International, 6(1): 1-9.

Akindele, S.O. 2001. Forestry Practices in Nigeria: An Overview

Akande, J. A,Larinde, S.L, Ntabe, E,Adu-Anning C. and B.O. Agbeja 2009. Towards ForestIndustrial Reform in Ghana, Nigeria and Cameroon.Discovery and Innovation Journal of AFORNET Special Edition, 19 (3): 181-189.

Alao, J. S. 2005. Capacity Building Modules in the Nigerian Forest Services. A Ph.D Thesis submitted to the University of Ibadan, Ibadan.301p.

Asiabaka, C. C. 1998. Agricultural Extension: A handbook for Development Practitioners. Pp 37.

Bada, S. O. 1994. Manpower Development and Training Needs in Nigerian Forestry. FORMECU.16p. 
Bada, S. O. and Popoola, L. 2005. Sustainable Forest Resource Development in Nigeria. Proceedings of the $30^{\text {th }}$ Annual Conference of the Forestry Association of Nigeria. Kaduna, Kaduna State, Nigeria. 727Pp.

Edet, D. I., Nchor, A. A. And Ekpe, G. A. 2017. Appraisal of Personnel Strength And Quality In Cross River State Forestry Commission, Cross River State, Nigeria. Nigerian Journal of Agriculture, Food and Environment. 13(2):179-185

Enabor, E. E. 1981. Manpower Requirement for Forestry in Ogun, Benue and Borno States of Nigeria. Reports to the Forestry Projects Monitoring and Evaluation Unit (FORMECU). Fed. Dept of Forestry Ibadan 71p.

Erakhrumen, A. A. (2007). State of Forestry Research and Education in Nigeria and Subsaharan Africa: Implications for Sustained Capacity Building and Renewable Natural Resources Development. Journal of Sustainable Development in Africa Vol. (9) 131-151Pp.

Faleyimu, O. I. 2010. Status of Forest Policy Implementation in South-West Nigeria. Unpublished Ph.D Thesis, University of Ibadan, Ibadan. April, 2010. Pp 271

Faleyimu, O. I. and Arowosoge, O. G .E. 2011. Status of forest policy implementation in Kaduna State, Nigeria. Australian Journal of Basic and Applied Science, 5(8): 995 - 1001.

FAO, 1970. Report of FAO Advisory Committee on Forestry Education $4^{\text {th }}$ Session, Ibadan Nigeria, July 1969, FAO Rome, Pp: 103. ISBN:92-5-103202-6.

Food and Agricultural Organization of the United Nations (FAO). 2003. Experience of Implementing National Forest Programmes in Nigeria. FAO Corporate Document Repository. Downloaded from http://www.fao.org/docrep/005/AC918E/AC918E00.htm on $17-04-$ 2017.

FAO. 2010. Developing effective forest policy: A guide. FAO paper 161, Rome, Italy. far, so good'Chemonics International for USAID, Guatemala.

Nigeria galleria, 2018. Wikipedia Google search.

Oguntala, A. B. 1994. Forestry Education at Technical Level. In: Processings World Forestry Congress Vol. 8: 87-94.

Popoola, L. 2014. Urban Renewal Debates: The Challenge of Greening Urban Environment in Nigeria. 55th Interdisciplinary Research of the Postgraduate School, University of Ibadan, Nigeria. ISBN: 978-978-50793-8-8. Postgraduate School, University of Ibadan. Pp 1-55. 